\title{
La doctrina del caudillaje en España: legitimidad política y poder ca- rismático durante el franquismo*
}

\author{
Enrique Moradiellos García \\ Universidad de Extremadura \\ negrin@unex.es
}

RESUMEN: El artículo examina las fuentes de fundamentación doctrinal carismática del poder del general Francisco Franco como Caudillo de España durante casi cuarenta años. Sobre la base de las variadas culturas políticas de la derecha española, se presenta la guerra civil de 1936-1939 como contexto generatriz de la nueva autoridad suprema y soberana asumida por Franco durante la contienda y mantenida con posteridad como legado de su victoria militar. El consecuente culto personal al Caudillo y las elaboraciones teóricas del caudillaje se adaptaron a las cambiantes circunstancias internacionales sin mengua de la justificación permanente de la autoridad indiscutida de Franco.

\section{Palabras clave: Franquismo; Francisco Franco; Caudillaje; Poder Carismático; Dictadura.}

The Doctrine of Caudillism in Spain: Political Legitimacy and Charismatic Power during Francoism

ABSTRACT: The article aims to analyze the sources of doctrinal justification of the charismatic power of General Francisco Franco as Caudillo of Spain for almost forty years. Taking into account the various political cultures of the Spanish Right, it shows the Civil War of 1936-39 as the seminal context for the new supreme and sovereign authority assumed by Franco during the conflict and preserved afterwards as a legacy of his military vic-

* Este trabajo se ha beneficiado del apoyo del Ministerio de Economía y Competitividad al proyecto de investigación HAR2013-41041-P titulado «Las caras de Franco: Funciones políticas y representaciones públicas del caudillo en el régimen franquista», dentro del Programa Estatal de Fomento de la Investigación Científica y Técnica de Excelencia. 
tory. The consequent personal cult to the Caudillo and the theoretical productions on Caudillaje leadership were adapted to changing international circumstances without any diminution of the permanent and supreme authority of Franco.

KEY WORDS: Francoism; Francisco Franco; Caudillism; Charismatic Power; Dictatorship.

Como recordaba en una obra clásica el maestro que fue Manuel GarcíaPelayo, todas las sociedades registradas en la historia han ido gestado diversos órdenes políticos que siempre descansaban sobre «unos sistemas de ideas y creencias destinados a mantener los valores en que se sustentaban, a consolidar la estructura en que se configuraban y a proporcionar (a sus integrantes) unas pautas de orientación y de acción» ${ }^{1}$. Ese conjunto de ideales, valores y principios orientativos de toda sociedad política humana, más o menos integrados, respetados o violados, conforman el material básico denotado por las distintas categorías conceptuales que tratan de describir su esencia, papel y funcionamiento: las «formas de poder político» (entendiendo aquí «poder» como capacidad de unos hombres para forzar la conducta de otros según su voluntad, en palabras de Hans Gerth y Charles Wright Mills); los «tipos de autoridad legítima» (siendo la «autoridad» un poder considerado «legítimo» porque su «fuerza» se convierte en «derecho» y la «obediencia» deviene un «deber», al modo de Max Weber); las «formas de dominación socioinstitucional» (que presuponen unas «relaciones de interacción» entre gobernantes y gobernados que exigen al menos prestigio del superior y subordinación del inferior, en la línea de Georg Simmel); o los patrones subyacentes de «las culturas políticas» (consideradas como sistemas de ideas-fuerza que tienen efectos en las dinámicas socio-políticas, a tenor de Gabriel Almond, Sidney Verba o Lucien Pye).

Las diversas fuerzas y tendencias socio-políticas que en España organizaron y ejecutaron la insurrección militar de julio de 1936, libraron y ganaron la guerra civil y establecieron un régimen institucional victorioso que duró casi cuarenta años, por supuesto que contaban con sus propias «culturas políticas» que sustentaban diferentes «tipos de autoridad legítima» y soportaban «formas de poder político y de dominación» bien perfiladas y conocidas. Todavía más. Como han demostrado claramente varios trabajos recientes (en particular los completos estudios de Ferran Gallego sobre «la formación de la cultura política del franquismo» y de Ismael Saz sobre «los nacionalismos franquistas»), la guerra propició una rápida convergencia de intereses y postulados entre todas esas culturas políticas de las derechas españolas antiliberales. Y

\footnotetext{
1 GARCÍA-PELAYO, 1981: 12.
} 
ello por la sencilla razón de que impuso la necesidad de mantenerse férreamente unidas contra el enemigo para superar los retos bélicos, lograr la victoria y sobrevivir sin riesgo de involución con posterioridad ${ }^{2}$.

\section{LAS CULTURAS POLÍticAS DE LA DERECHA ANTILIBERAL ESPAÑOLA}

En vísperas de la guerra civil, el espacio socio-político de las culturas políticas de la derecha antiliberal española (el también llamado «pensamiento reaccionario español»o «frente contrarrevolucionario») permitía registrar un mínimo de cuatro grandes corrientes operativas muy consolidadas y arraigadas de manera desigual en la población española. Y, por supuesto, como han subrayado diversos analistas, cada una de ellas contaba con su respectivo repertorio de doctrinas depuradas por años de tradición, nombres prestigiosos, organizaciones vetustas o modernizadas y fórmulas de acción socio-política más o menos eficaces con sus propias masas de seguidores y fieles ${ }^{3}$.

Ante todo, debe subrayarse el inmenso peso del catolicismo político, heredero del veterano «agustinismo político» promovido por la jerarquía eclesiástica y sus portavoces intelectuales en sus múltiples variantes («Toda autoridad procede de Dios»: con su corolario de subordinación del orden humano al orden divino superior y anterior). Un movimiento articulado durante la Segunda República por la Confederación Española de Derechas Autónomas (CEDA) y cuyo perfil político era claramente confesional, corporativo, jerárquico y conservador, empero su táctica política posibilista y pragmática en el quinquenio republicano y hasta la debacle de las elecciones generales de febrero de 1936. El propio fracaso de esa estrategia posibilista y el estallido de la guerra arruinarían el capital político de la CEDA como partido y de su máximo dirigente, José María Gil Robles, que sólo cooperaría con la insurrección desde Portugal y en un segundo plano. Pero no haría desaparecer, ni mucho menos, el acervo doctrinal, el personal político y las masas de seguidores del catolicismo político español. No en vano, la ideología del nacional-catolicismo y la idea de «Cruzada por Dios y por España» surgirían de su seno como potentes fórmulas ideológicas de legitimación de la sublevación y su Nuevo Estado ${ }^{4}$.

En segundo orden, y a gran distancia en cuanto apoyo popular (pero no en cuanto a personal político capacitado), cabe mencionar al monarquismo auto-

2 GALLEGO, 2014. SAZ, 2003. A ellos cabría sumar, desde perspectivas más reducidas pero interesantes, el trabajo previo de ANDRÉS-GALLEGO, 1978.

3 Una acertada exposición de esta panorámica debe mencionar a PRESTON, 1986; RODRÍGUEZ JIMÉNEZ, 1997; GONZÁLEZ CUEVAS, 2005; NOVELLA, 2007; y GONZÁLEZ CALLEJA, 2011.

4 TUSELL, 1974, vol. 1. MONTERO, 1977. ÁlVAREZ BOLADO, 1995. DI FEBO, 2012. MONTERO, 2008. CUENCA TORIBIO, 2008. 
ritario alfonsino, que acababa de sufrir el colapso del régimen militar primorriverista y mantenía relaciones simbióticas con el catolicismo político sólo quebradas por el grado de fidelidad respectivo a la Monarquía como fórmula institucional. Tras la debacle de 1931 el monarquismo acentuó la crítica de la tradición liberal-democrática en favor de objetivos como el fin de la política de partidos y parlamentos, la instauración de gobiernos tecnocráticos asépticos y fuertes, la refundación del nacionalismo integral y la restauración de la identidad de trono y altar en proyectos de Estados corporativos y disciplinados. Era la alternativa que alentaría con singular coherencia doctrinal la revista Acción Española en la estela del integralismo francés maurresiano, cuyo preclaro portavoz sería José Calvo Sotelo, antiguo hombre fuerte de la dictadura que sería asesinado en vísperas de la sublevación de 1936, eliminando a uno de los más prestigiados líderes del movimiento monárquico autoritario ${ }^{5}$.

En tercer lugar, seguía presente en algunos núcleos geográficos (sobre todo, las provincias vascas y Navarra) la cultura política del viejo tradicionalismo carlista, la más antigua de las corrientes políticas anti-liberales y la más integrista en el plano religioso y moral. Renovado desde principios del siglo XX por figuras como Juan Vázquez de Mella y Víctor Pradera, el tradicionalismo ofrecía una verdadera cantera de alternativas políticas e ideológicas al «agotamiento» del sistema liberal y a la «disolución» de la idea nacional con mimbres variados y progresivamente confluyentes con los nuevos postulados del alfonsinismo y del autoritarismo corporativo católico. Su reducida base territorial, unida al secular fracaso y debilidad de sus pretendientes dinásticos $\mathrm{y}$ al limitado prestigio nacional de sus dirigentes, cercenaba su potencia y capacidad de maniobra. Pero la crisis abierta con la proclamación de la República en abril de 1931 parecía corroborar retrospectivamente el acierto de su intransigencia antiliberal y de su catolicismo beligerante ${ }^{6}$.

Y, finalmente, desde 1933, había cristalizado la alternativa fascista inspirada en el modelo italiano de la mano de la Falange Española, fundada por José Antonio Primo de Rivera, el hijo del dictador que sería fusilado por los republicanos cuatro meses después de iniciada la guerra, dejando a su movimiento descabezado en una coyuntura crítica. A tono con la inspiración mussoliniana, la fórmula falangista proyectaba un nuevo concepto de Estado totalitario completado con la militarización política de la sociedad, la confraternización plebeya de una ciudadanía jerarquizada y la doctrina del liderazgo carismático asentado en una religión civil y secular de la patria hispostasiada y divinizada. Sin embargo, pese a su modernidad, esteticismo y atractivo juvenil, el falangismo apenas lograría competir con las otras alterna-

\footnotetext{
5 MORODO, 1985. GIL PECHARROMÁN, 1994. GONZÁLEZ CUEVAS, 1998.

6 BLINKHORN, 1979. CANAL, 2006.
} 
tivas antes de que la guerra ofreciera una oportunidad única para su expansión y consolidación como movimiento y partido de masas ${ }^{7}$.

En todo caso, fuera cual fuera el peso e influencia de cada una de esas culturas políticas, lo cierto es que entre ellas se había producido un proceso de convergencia y cooperación muy intenso durante el período republicano y, particularmente, después de la crisis de octubre de 1934 y tras la derrota electoral de febrero de 1936. Un proceso exigido por la percepción de la gravedad del riesgo afrontado y de la fuerza del enemigo común: en primer término, la realidad efectiva de la democracia liberal reformista y, tras ella, la amenaza de la revolución social como su derivación potencial y obligada. No en vano, como advertía el líder fascista Onésimo Redondo ya en 1931 a todos los interesados: «Jacobinismo es hoy bolchevismo. O algo que dejará a éste franco y libre paso». Y la réplica desde filas monárquicas alfonsinas, en la voz del periodista Joaquín Arrarás en 1932, no dejaba dudas de la conformidad con ese juicio y el corolario derivado: «la adversidad es vínculo que hoy reúne y concentra y aprieta a la familia toda ${ }^{8}$. Sin olvidar que la relativa facilidad de ese proceso de convergencia se fundaba en la presencia de varios componentes compartidos en mayor o menor dosis por todas esas culturas: la afirmación de la tradición católica de la nación como componente definitorio irrenunciable; la defensa de un nacionalismo palingenésico e integral que no admitía dudas ni pactos con la «Anti-España»; la promoción de una idea de reforma del Estado que rompía con el liberalismo y la democracia de manera radical; la concepción de las relaciones sociales bajo prismas jerárquicos y de disciplina militarizada que pretendía atajar las divisiones sociales y las luchas de clases; y, progresivamente, la convicción de que sólo la violencia organizada y preferentemente la fuerza de las armas militares podrían atajar la disolución social y nacional.

En efecto, a partir de la derrota electoral de febrero de 1936, el protagonismo clave en la reacción violenta contra esos peligros mortales dejó de estar en manos de los movimientos partidistas civiles para pasar a los mandos del ejército español, en un proceso de creciente satelización política bien percibida por todos los contemporáneos y claramente demandada por muchos líderes políticos conscientes de la situación. El propio Calvo Sotelo había exigido ya en enero de 1936 ese retorno del pretorianismo militar más tradicional con palabras claras y precisas:

No faltará quien sorprenda en estas palabras una invocación indirecta a la fuerza. Pues bien. Sí, la hay (...). ¿A cuál? A la orgánica: a la fuerza militar puesta al ser-

7 THOMÀS, 1999; 2011. GALLEGO, 2005. GALLEGO y MORENTE, 2005. SAZ, 2004. RUIZ CARNICER, 2013.

8 GALLEGO, 2014: 125 y 137. 
vicio del Estado. (...) Hoy el Ejército es la base de sustentación de la Patria. Ha subido de la categoría de brazo ejecutor, ciego, sordo y mudo, a la de columna vertebral, sin la cual no es posible la vida. (...) Cuando las hordas rojas del comunismo avanzan, sólo se concibe un freno: la fuerza del Estado y la transfusión de las virtudes militares -obediencia, disciplina y jerarquía- a la sociedad misma, para que ellas desalojen los fermentos malsanos que ha sembrado el marxismo. Por eso invoco al Ejército y pido al patriotismo que lo impulse 9 .

Y no otra cosa llegaron a sugerir en vísperas de la sublevación igualmente tanto Gil Robles como José Antonio Primo de Rivera, a pesar de su temor a las consecuencias que ese protagonismo militar corporativo pudiera tener para sus propios planes políticos. José Antonio lo hizo en su «Carta a los Militares de España» remitida desde la cárcel el 4 de mayo de 1936: «Sin vuestra fuerza, soldados, nos será titánicamente difícil triunfar en la lucha. (...) El que España siga siendo depende de vosotros». Gil Robles lo había hecho una quincena antes desde la tribuna parlamentaria al advertir: "cuando la guerra civil estalle en España, que se sepa que las armas las ha cargado la incuria de un Gobierno que no ha sabido cumplir su deber» ${ }^{10}$.

\section{LA GUERRA CIVIL COMO TIEMPO MATRIZ DEL CAUDILLAJE FRANQUISTA}

Cuando la sublevación se inició el 17 de julio de 1936 y la guerra fue su consecuencia, todo el arsenal léxico, ideológico y doctrinal de la tradición militarista y africanista del ejército español se puso en marcha de manera abrumadora. De hecho, cualquiera que fuera la mayor o menor simpatía de los jefes militares sublevados por una u otra «cultura política» de las derechas españolas (y es evidente que predominaban los católicos y monárquicos sobre carlistas y falangistas), todos estaban totalmente de acuerdo en el carácter exclusivamente militar del movimiento de fuerza en curso. Es improbable que ninguno objetara un ápice de lo que el general Mola declararía al respecto y como aviso a navegantes a mediados de septiembre de 1936 (justo antes de que la Junta de Defensa Nacional decretara «un apartamiento absoluto de todo partidismo político» y la subordinación de todos «al Ejército, símbolo efectivo de la unidad nacional»):

Tengo una confianza ciega en estos muchachos impetuosos que hoy exigen (apenas velada referencia a las milicias partidistas, falangistas y carlistas); pero tengan bien entendido que en esa obra de reconstrucción nacional que se han propuesto realizar

9 Palabras pronunciadas el 12 de enero de 1936. ARRARÁS, 1968, vol. 4: 13.

10 PRIMO DE RIVERA, 1966: 929. Declaraciones de Gil Robles el 15 de abril de 1936 reproducidas en ÁLVAREZ TARDÍO, 2011: 416. 
y que realizarán, ¿quién lo duda?, en esa formidable empresa hemos de poner nosotros, los militares, sus cimientos; hemos de iniciarla; nos corresponde por derecho propio, porque es ése el anhelo nacional, porque tenemos un concepto exacto de nuestro poder y porque únicamente nosotros podremos consolidar la unión del pueblo con el Ejército, distanciados hasta el 19 de julio, por las absurdas propagandas de un intelectualismo estúpido y una política suicidas ${ }^{11}$.

No hace falta subrayar que los escasos desafíos a esa exclusividad del poder militar en la zona insurgente fueron tajantemente cortados de raíz por las autoridades castrenses desde el principio y hasta el final. Basta recordar las dos intervenciones expeditivas de Franco ya como Generalísimo de los Ejércitos: $1^{\circ}$ ) la expulsión de España en diciembre de 1936 del líder carlista Manuel Fal Conde por su pretensión de hacer de las milicias requetés un brazo virtualmente autónomo del resto del Ejército; y $2^{\circ}$ ) la detención, proceso y condena a dos penas de muerte de Manuel Hedilla (sucesor provisional en la jefatura falangista de José Antonio) y algunos otros compañeros de dirección falangista por su tibia oposición a la unificación forzosa de partidos políticos decretada en abril de 1937.

En este sentido, como muestran los últimos estudios sobre la articulación del esfuerzo bélico insurgente (a título de ejemplo, los trabajos de Gabriel Cardona, Jorge Martínez Reverte, Michael Seidman o James Matthews), es evidente que el aporte humano del voluntariado miliciano de Falange y el Tradicionalismo (más que de Renovación) fue muy destacado y apreciado por los mandos militares sublevados: a finales de 1936 suponían casi 37.000 milicianos falangistas, 22.100 requetés carlistas y poco más de 6.000 monárqui$\cos$ alfonsinos. Pero también es evidente que esas «milicias nacionales» (siempre integradas en unidades militares y bajo mandos profesionales) nunca llegaron a ser más del 34 por ciento de las fuerzas movilizadas hasta el otoño de 1936: en torno a 65.000 hombres para un total de 189.000 soldados en armas. Aún más. Esa cantera de tropas voluntarias, impulsadas por su compromiso político e ideológico partidista dejó muy pronto de ser la matriz principal de reclutamiento ${ }^{12}$. Frente al aporte miliciano, el Ejército sublevado utilizó y perfeccionó los tradicionales canales de reclutamiento militar obligatorio porque la guerra no podía librarse con tan pocos hombres voluntarios en armas y hubo que recurrir a la movilización forzosa y forzada de otros jóvenes y no tan jóvenes (entre 18 y 45 años) para mantener las operaciones y nutrir la mano de obra bélica: los ejércitos franquistas movilizarían así a 1,2

11 Discurso radiado del 13 de septiembre de 1936. MOLA, 1940: 1184. El decreto de 25 de septiembre citado en el Boletín de 28 de septiembre de 1936. La aceptación de esa demanda militar de apoyo civil subordinado se aprecia en ORELLA, 2001.

12 CARDONA, 2006. MARTÍNEZ REVERTE, 2009. SEIDMAN, 2012. MATTHEWS, 2013. 
millones de hombres en 15 reemplazos hasta principios de 1939. No es poco éxito el que hay detrás de esa enorme operación logística de «encuadramiento» humano y material realizado por militares, bajo preceptos militares y en torno a una lógica castrense bien engrasada y veterana.

En cuanto a «mitos movilizadores» para estimular el celo combatiente, sin menospreciar los aportes falangistas con su ropaje de modernidad y prestigio internacional, lo cierto es que los motivos fundamentales, recurrentes y omnipresentes, que circularon por «el Ejército de Franco» fueron más clásicos y tradicionales que otra cosa. Ante todo, el nacionalismo español unitarista, integralista e historicista: la «España, evangelizadora de la mitad del orbe; España, martillo de herejes, luz de Trento, espada de Roma, cuna de San Ignacio» que alabara Marcelino Menéndez y Pelayo y aprendieran a amar los cadetes de las Academias Militares desde finales del siglo XIX. Y, a su lado, el catolicismo identificado con la idea de Cruzada «por Dios y por España» que llevaba siglos proclamando la idea de «España como país predilecto y predestinado para la realización del Reino de Cristo». En este punto, todo parece indicar que los discursos de movilización de masas del bando insurgente recurrieron por inercia y por defecto a lo que era acervo común y sustantivo en todas las derechas españolas y en el alma de las dos corporaciones burocráticas que articulaban el ser y el hacer del Nuevo Estado en construcción: «el culto místico hacia la nación» de los militares que sentían al Ejército «como la única institución patriótica y poseedora de la verdad»; y «la teología política del nacional-catolicismo» de los sacerdotes y su discurso de la Cruzada providencial y purificadora ${ }^{13}$. Al igual que no dejó de ser bastante clásico el instrumento orgánico encargado de la «moral» en las filas en dicho ejército: las tenencias vicarias o servicios de capellanes castrenses encargados de los «auxilios espirituales». En palabras muy recientes de James Matthews:

La alianza entre la Iglesia y los militares se fraguó muy pronto tras el alzamiento y, durante la mayor parte de la Guerra Civil, «nacional» y «católico» fueron palabras sinónimas. (...) El lenguaje sacralizado del espíritu de Cruzada tenía el poder de hacer la muerte tolerable, e incluso positiva, en el discurso oficial. Los hombres que caían eran mártires de la causa y por ello «incorporados a la iconografía de la adoración». Esto se aprecia en los lemas pintados en las fachadas de los edificios de la España nacional: «Ante Dios no serás un héroe anónimo» ${ }^{14}$.

Precisamente uno de los focos de convergencia de todas las culturas políticas de la derecha antiliberal española fue la doctrina del caudillaje como fór-

13 LOSADA, 1990: 25. CARDONA, 2008: 18. DI FEBO, 2012: 17, 31 y 56. La cita previa de Menéndez y Pelayo (de 1882) formaba parte de su libro Historia de los heterodoxos españoles y fue profusamente difundida en todo tipo de formatos. Uno de sus grandes divulgadores en los años treinta fue un prestigioso general, Jorge Vigón. VIGÓN, 1934: 354.

14 MATTHEWS, 2013: 140 y 144. 
mula de suprema autoridad, mando y gobierno exigida por las circunstancias bélicas, y ajustada a las tradiciones nacionales y a los imperativos internacionales. En este punto, la coincidencia de todos fue unánime y el resultado bien conocido: el encumbramiento de Franco a la condición de Caudillo carismático y providencial de magistratura vitalicia, plenos poderes constituyentes y juicio soberano e inapelable. Aunque, eso sí, para unos fuera sobre todo (o sólo) Caudillo de la Victoria por triunfo militar, Caudillo de la Cruzada por voluntad divina o Caudillo de la Revolución Nacional por liderazgo político falangista. Y, por supuesto, el propio Caudillo se ocuparía siempre de mantener sus tres fuentes de legitimidad armónicamente equilibradas y coordinadas, sin menoscabo de su autoridad suprema, soberana, arbitral y decisoria ${ }^{15}$.

Los mandos militares sublevados iniciaron el proceso por su propio protagonismo en la insurrección y en la dirección de las operaciones bélicas y fueron ellos quienes, a finales de septiembre de 1936, procedieron a elegir al general Franco como «Generalísimo de los Ejércitos» y «Jefe del Gobierno del Estado» sin consulta con nadie ni intermediación de nadie, al margen de las preferencias políticas expresadas desde Roma y Berlín, que eran mucho más influyentes que cualquier otra opinión política interna española ${ }^{16}$. La imposición de la «unidad de mando» en torno a Franco estaba a tono con la visión jerárquica y disciplinada de los jefes militares ante una situación de emergencia nacional, respondía al «principio de autoridad y unidad» indivisa y no dejaba de ser «un signo de cesarismo» encomiable por sus éxitos («Los césares eran generales victoriosos», rezaría una consigna inmediatamente adoptada por la propaganda insurgente) ${ }^{17}$. El recurso al vocablo «Caudillo» era igualmente lógico habida cuenta de su amplia circulación previa para denotar al jefe militar heroico y admirable que, además, asumía atribuciones políticas literalmente omnímodas. De hecho, ese término permitía fusionar sin distingos en una sola magistratura las dos formalmente «transferidas»: la autoridad militar para librar la guerra («Generalísimo») y la autoridad política para edificar el aparato estatal alternativo («Jefe del Estado»). La consagración definitiva del Caudillo ante sus compañeros de armas tuvo lugar con la ceremonia del desfile de la Victoria celebrado en Madrid el 19 de mayo de 1939, cuando Franco contempló el paso de más de cien mil soldados (los triunfales «Ejércitos de Franco») y recibió la más alta condecoración militar española por su proeza descrita en el decreto correspondiente con estas palabras:

Ganada completamente la guerra, que la Anti-España desencadenó sobre nuestra Patria, la nación entera y a la cabeza todos los Caballeros de la Gran Cruz Laurea-

15 Certeros análisis de ese proceso de construcción carismática en PRESTON, 1994; REIG TAPIA, 2005; SEVILLANO, 2010; ZENOBI, 2011; y CAZORLA, 2015.

16 Así lo demostró PRESTON, 1994: 221-253.

17 JORDANA DE POZAS, 1941. 
da de San Fernando, reunidos en capítulo, solicitaron la concesión de la Gran Cruz Laureada de San Fernando para el Caudillo, que con su genio supo ganar la guerra (...). No se trata ya de un general en jefe que llena cumplidamente los requisitos que exige el artículo 35 del reglamento de la Orden de San Fernando para ingresar en ella, sino que en el caso presente es el gran Caudillo que salvó a su Patria, devolviéndole la independencia y el orden y que además rindió al mundo entero el mejor servicio que podía prestar para la paz al derrotar al bolchevismo en nuestro solar patrio salvando con ello una civilización seriamente amenazada ${ }^{18}$.

En el caso de la jerarquía eclesiástica, la casi inmediata conversión del esfuerzo bélico insurgente en una Cruzada por la fe de Cristo fue muy pronto completada con la elevación de Franco a la categoría de homo missus a Deo, enviado de la Divina Providencia para defender la Iglesia y restaurar su papel en la nación española a tono con los postulados del nacional-catolicismo. El cardenal primado y arzobispo de Toledo, Isidro Gomá, informó al Vaticano desde el principio que Franco era el más favorable hacia la Iglesia de los mandos sublevados («Quien tiene mejores antecedentes en este punto es el Generalísimo Franco, católico práctico de toda la vida»). Y recibió pronto confirmación de esa buena disposición del interesado en forma de medidas legales, económicas y culturales que restablecían los derechos y privilegios del catolicismo suprimidos por la República ${ }^{19}$. El tránsito hacia la fórmula de «Caudillo por la Gracia de Dios» fue muy rápido porque enlazaba con la vieja idea teológica de la autoridad como investidura divina y remedaba la fórmula del Rex per Gratia Dei habitual en la tradición histórica española y católica. Terminada la guerra, al día siguiente del Desfile de la Victoria, la ceremonia del Te Deum de acción de gracias por el triunfo celebrada en la Iglesia de Santa Bárbara de Madrid, con Franco entrando bajo palio y recibido por la jerarquía episcopal en pleno, sólo confirmó una realidad previa ahora sacralizada por la oración pública del Primado:

Dios a quien todos se someten, a quien todas las cosas sirven, haz que los tiempos de tu buen siervo el Caudillo Francisco Franco sean tiempos de paz y alegría, para que aquél a quien pusimos al frente de nuestro pueblo bajo tu guía tenga paz y días de gloria. Te rogamos hoy, Señor de los señores, para que mires benignamente

18 Decreto de 19 de mayo de 1939. Reproducido en el diario $A B C, 20$ de mayo de 1939. Un análisis del desfile y sus preparativos en DI FEBO, 2012: 97-113. Platón recuerda que la exhibición fue «una de las mayores de su género celebradas en el mundo durante este siglo» y constituyó «la apoteosis del que había asumido para sí la denominación de Ejército Nacional» y de su «joven Generalísimo». PLATÓN, 2001: 12 y 15.

19 El juicio de Gomá en sus informes confidenciales para el Vaticano de 24 de octubre y 9 de noviembre de 1936. RODRÍGUEZ AISA, 1981: 32 y 36. Sobre la traumática experiencia de la Iglesia con la modernidad secular y la etapa republicana véase LANNON, 1987. 
desde el trono de tu Majestad a nuestro Caudillo Francisco Franco al que diste un pueblo sujeto a su gobierno asistiéndole en todo tu voluntad ${ }^{20}$.

Por lo que respecta al partido político unificado, su impronta dominante falangista asumió perfectamente el caudillaje de Franco porque concordaba con su propia concepción jerárquica y carismática del liderazgo político. Además, la pérdida de José Antonio y su difícil reemplazo en el mando de la vieja Falange habían minado crucialmente al partido, impidiéndole oponer resistencia a la decisión de Franco, mediante decreto del 19 de abril de 1937, de apropiarse de sus estructuras, simbologías y masas para fusionarlas con otros grupos políticos derechistas y fundar así un nuevo partido unificado que sirviera de tercer pilar, junto al Ejército y la Iglesia, para su régimen de poder personal caudillista: la Falange Española Tradicionalista y de las JONS $^{21}$. Como reconocería Dionisio Ridruejo, entonces joven líder falangista a cargo de la propaganda oficial, oponerse hubiera sido suicida y aceptarlo redundaba en beneficio de ambas partes porque solucionaba un problema real: «un movimiento sin Caudillo y un Caudillo sin movimiento». En consecuencia, la conversión de Franco (un caudillo militar y con sanción religiosa) en Caudillo de la nueva Falange fue aceptada como única vía para realizar la «Revolución nacional-sindicalista» al compás de la guerra y gracias a un «caudillaje cimentado en la potencia militar» con poderes omnímodos y supremos pero asesorado y aconsejado por sus fieles seguidores y servidores:

El Caudillo no está limitado más que por su propia voluntad, pero esta voluntad limitativa es justamente la razón de existir del movimiento: los dogmas proclamados, las minorías elegidas y la fe del pueblo abierta. Así el movimiento - instrumento del Caudillo (del Estado que en él reside) - , populariza, de una parte, su voluntad y sirve, de otra, de piedra de toque y voz de consejo para las decisiones de esa misma voluntad que otros órganos (Ejército para el poderío, burocracia para la administración) ejecutarán ${ }^{22}$.

La convergencia programática de las tres instituciones en torno a la necesidad del caudillaje de Franco como virtual César victorioso, providencial y soberano cimentó el consecuente culto a la mítica personalidad carismática que se mantendría hasta su propio fallecimiento en 1975. Eso sí, con variaciones de intensidad y modalidad de mayor o menor intensidad. Por eso, unas

20 Oración y contexto de la ceremonia analizados en DI FEBO, 2012: 109-118. Las fuentes canónicas de esa concepción cristiana de la autoridad pública fueron bien expuestas por la obra clásica de ULLMANN, 2013 (edición original de 1965). Su adaptación contemporánea en España puede verse en NOVELLA, 2007.

21 Un reciente análisis de ese complejo proceso en THOMÀS, 2014.

22 RIDRUEJO, 1938: 35-38. 
veces se subrayó su condición de Caudillo militar de la Victoria (durante la guerra, cuando la categoría de Generalísimo se utilizaba con profusión en los medios de propaganda y el régimen se preciaba de ser un nuevo directorio militar similar al de 1923 mutatis mutandis). Otras veces, se enfatizó su calidad de Caudillo falangista de la Revolución nacional (como sucedió entre 1937 y 1942, cuando el contexto internacional acentuó las tentaciones de emulación de los valedores fascistas y nazis y el régimen se presentaba como un totalitarismo español sin complejos). Incluso otras veces se hacía hincapié en su perfil de Caudillo religioso de la Cruzada (desde 1943 y hasta 1959, cuando la legitimidad nacional-católica se convirtió en carta de presentación ante las potencias vencedoras en la guerra mundial y durante la primera postguerra). Y, finalmente, otras veces se proyectaría su papel de Caudillo de España y «Jefe del Estado» sin más adjetivos discutibles (como ocurriría a partir de 1959, cuando la eficacia tecnocrática y los éxitos modernizadores servirían para encontrar nuevas legitimidades civiles y «de ejercicio» más respetables en el mundo exterior).

Y por esa misma versatilidad de funciones y situaciones, «el Caudillo» se convirtió, de hecho antes que de derecho, en la «suprema y única institución» del régimen franquista. Por una razón muy certeramente apuntada por el escritor Ernesto Giménez Caballero en una de sus arengas propagandísticas más difundidas entre «los combatientes» durante la guerra civil, que era también una llamada al cierre de filas de «todos» en torno a su persona por motivos de mera supervivencia:

Nosotros los combatientes - este ejército nuevo y tradicional de España- sabemos quién es Franco y le adoramos hasta el fanatismo por saberlo. (...) Y todos saben - en especial los rojos, los enemigos-, que sin FRANCO todos nuestros sueños, todos nuestros sacrificios, «todo» y «todos», «totalitariamente», se hundiría y se perdería. (...) Y ante esta grandeza y esta gloria ¡ESPAÑA! ESPAÑA DE FRANCO Y LA FALANGE, FALANGE DE DIOS Y DE LOS EJÉRCITOS ${ }^{23}$.

\section{CARISMA Y LEGITIMIDAD POLÍTICA: EL SUSTRATO DOCTRINAL DEL CAUDI- LLAJE}

Por supuesto, esa construcción de un régimen caudillista de poder personal soberano y constituyente no era ni mucho menos una excepción insólita y singular de la historia española del siglo XX. Era, más bien, uno de los casos más definidos de los nuevos tipos de regímenes dictatoriales surgidos en Europa durante la «era de los dictadores» que tuvo su eclosión principal en los

\footnotetext{
23 GIMÉNEZ CABALLERO, 1938: 14-15 y 29.
} 
años de guerras y entreguerras (1914-1945). Unos regímenes que, a diferencia de las previas dictaduras decimonónicas (ya monárquicas ya militares), se configuraban mediante un proceso de «carismatización» de la autoridad personal y «en torno al culto al líder misionario y ejemplar destinado a rehacer la unidad nacional y conducir a su pueblo hacia una nueva era ${ }^{24}$. Si bien sus raíces cabe buscarlas en el papel central que la idea de un líder fuerte y poderoso tiene en el pensamiento político occidental desde los tiempos de Alejandro Magno y César, su nueva modulación en los albores del siglo XX era deudora de las aportaciones de Thomas Carlyle (con su romántico elogio al líder heroico), Friedrich Nietzsche (con su teoría del super-hombre dominador), Gustave Le Bon (con su postulado de una era de masas que demandaba grandes líderes conductores) y la escuela de politólogos que habían puesto en cuestión el fundamento meramente racional de los sistemas políticos liberales occidentales (desde Roberto Michels a Gaetano Mosca, pasando por Vilfredo Pareto) $)^{25}$.

El triunfo de las democracias en la Gran Guerra de 1914-1918 no mitigó en absoluto esa tendencia a la personalización de la autoridad suprema en un líder carismático porque sus efectos disolventes sobre fronteras, mentalidades y sociedades generaron el contexto para la aparición de una pléyade de nuevos dictadores «soberanos» portadores de «credos de redención nacional» y «evangelios de la violencia purificadora» por todo el continente: desde Lenin en Rusia en 1917 a Mussolini en Italia en 1922, pasando por el mariscal Pilsudski en Polonia en 1919, el regente Horthy en Hungría en 1920 o Kemal Ataturk en Turquía en 1921, sin olvidar igualmente los «regímenes militares presidencialistas autoritarios» establecidos en todas las repúblicas bálticas y los estados balcánicos a partir de mediados de los años veinte y con posterioridad. De hecho, la experiencia traumática de la guerra total recién terminada dejaría un pesado legado que haría de la época de entreguerras una era de conflictos continentales agudamente percibidos por muchos contemporáneos $\mathrm{y}$ analistas como una verdadera 《guerra civil europea» ${ }^{26}$.

En ese contexto convulso, el fenómeno de la aparición de dictaduras tan novedosas y movimientos políticos afines había sido tan evidente que había propiciado la formulación por Max Weber en 1921 de su concepto de «autoridad carismática» como uno de los tres tipos de «fundamentación legítima de la autoridad política» existentes. Weber utilizó el término «carisma» (del griego charis, traducido al latín como gratia) en su sentido original de cuali-

24 EATWELL, 2006: 127-137. Véase el contexto general en BESIER y STOKLOSA, 2013.

25 El contexto de ese proceso intelectual se describe en los análisis clásicos de HUGHES, 1972; BRACHER, 1984; MOSSE, 1990; y MAZOWER, 2001.

26 TRAVERSO, 2009. CASANOVA, 2011. 
dad especial y sobresaliente de una persona que parece investida de un don original, de una gracia particular y luminosa, que suscita devoción en los demás y reverencia ante sus pronunciamientos y decisiones. Y trasladó su uso desde los primeros ámbitos religiosos y sacros (el mago, el profeta) a los nuevos tiempos políticos para denotar con el término el aura de santidad e infalibilidad de los nuevos dirigentes autocráticos que suscitaban la «idolatría popular» y resucitaban en parte «el antiguo culto del soberano divinizado» ${ }^{27}$.

El nuevo tipo de autoridad carismática weberiana se contraponía y codeterminaba con los dos tipos básicos registrados en la historia: la autoridad «tradicional» (que reposaba en la costumbre y el derecho consuetudinario, ya fuera de orden dinástico o teocrático) y la autoridad «racional» (legalmente objetivada mediante normas e instituciones supraindividuales, ya fueran representativas condicionadas, plebiscitarias o liberal-democráticas). A juicio de Weber, la «dominación carismática» se basaba en la «entrega extraordinaria a la santidad, heroísmo o ejemplaridad de una persona y del ordenamiento creado o revelado por esta persona». Y su contraste con las otras formas de legitimación derivaba de esa personalización extrema del fundamento del deber de obediencia a un mando único, sobresaliente y excepcional:

\begin{abstract}
En el caso de la dominación legal, la obediencia se presta a un ordenamiento legal impersonal y objetivo y a las personas establecidas por ese ordenamiento en virtud de la legalidad formal de sus órdenes y dentro del ámbito de esas personas. En el caso de la dominación tradicional se presta obediencia a la persona competente en virtud de la tradición y vinculada a la tradición en virtud de la lealtad personal. En el caso de la dominación carismática, se obedece al líder con cualidades carismáticas en cuanto tal en virtud de la confianza personal en su heroísmo, revelación, o ejemplaridad dentro del ámbito en el que se inscriba la creencia en el carisma de aqué ${ }^{28}$.
\end{abstract}

Tomando como parámetro conceptual esa fecunda categoría weberiana, los tratadistas de la época y posteriores subrayarían la novedad de los nuevos regímenes carismáticos que concentraban todo el poder estatal en una persona singular (el «poder personal» de Georges Burdeau) que era depositaria de la plenitudo potestatis, de manera vitalicia, sin limitación temporal y de manera incontestada. Se conformaba así un moderno dictador que, como subrayaba satisfecho el jurista Carl Schmitt en 1921, ya no era sólo mero dictador comisario (limitado al desempeño de una misión) sino verdadero dictador soberano y constituyente (porque era fuente de derecho y fundaba un nuevo régimen) ${ }^{29}$.

27 CAVALLI, 1995: 6-7 y 83-84. En el mismo sentido véase LINDHOLM, 2012.

28 WEBER, 2007: 75. WEBER, 2014.

29 SCHMITT, 2013. La primera edición alemana del texto es de 1921, el mismo año de formulación del concepto de «autoridad carismática» de Weber. El concepto de «poder personal» de Burdeau (reformulado ya después de 1945) se expone en BADÍA, 1964: 85-121. 
En definitiva, el nuevo dictador carismático definía una magistratura de poder absoluto excepcional e irrepetible precisamente por ese "carisma» que debe entenderse como cualidad del gobernante soberano ante la cual los gobernados se someten de facto y de iure, reconociéndole su legitimidad, su prestigio y su autoridad en función de su excepcionalidad y transcendencia para el país, la nación o el grupo considerado y afectado por su emergencia y cristalización. Era una especie de «inmenso César» de carne y hueso, portador de una «misión extraordinaria» por ser el «salvador» de una nación, pueblo o clase y la garantía de su «renacimiento»: el artífice y destinatario de unas nuevas formas de «religión política» civil o de una sacralización religiosa de la vida política ${ }^{30}$. Esa fue la novedosa doctrina de legitimación del poder omnímodo del fascismo italiano en la persona de Mussolini, del nacionalsocialismo en la figura de Hitler e incluso del comunismo soviético en torno a Stalin, todos ellos modelos conocidos y difundidos mucho antes de que la guerra española creara el contexto para la aplicación de sus principios y postulados al caso de Franco ${ }^{31}$.

A título de ejemplo ilustrativo de lo que significaba esa nueva legitimidad carismática como fuente de autoridad soberana, cabe recordar el grado de culto personal mitificado al Duce de Italia que generó el fascismo como parte central de su «religión política» civil y secular (según la formulación de Emilio Gentile). En marzo de 1934 el órgano de las juventudes fascistas proclamaba las virtudes míticas y sobrenaturales del «nuevo Dios de Italia» con estas fórmulas retóricas habituales hasta casi el final del régimen:

Su figura descuella, ya monolítica, en la actualidad, en la historia, en las proyecciones hacia el porvenir, dominando hombres y cosas, como príncipe de los hombres de Estado, como genio de la Estirpe, como redentor de Italia, como romano, en la realidad y en el mito, de Roma imperial, como personificación y síntesis de la idea-Populus, como gran iniciado (...). Él siguió desde el principio la práctica del Héroe (que) parte solo a conquistar el mundo, que existe, antes y únicamente en sus elaboraciones del espíritu (...). Mussolini ha sido el Héroe en una luminosidad solar, es el Genio inspirador y creador: es el animador que arrastra y conquista; es Él: la entereza maciza del mito y de la realidad ${ }^{32}$.

Para el caso posterior del nacional-socialismo, resulta conveniente recordar los rasgos y contextos que, según el análisis antológico de Franz Neumann (ya en 1942), eran características esenciales de aquella «religión germánica» que respondía a un concepto de liderazgo político definido bajo la fórmula del Führer Prinzip:

30 CAVALLI, 1995: 84-85.

31 KERSHAW, 2003. PASSERINI, 1991. DAVIS y HARRIS, 2005. OVERY, 2006.

32 GENTILE, 2007: 219-220. Véase al respecto el completo repaso de DE FELICE y GOGLIA, 1983. 
Adolf Hitler es el líder supremo. Combina las funciones de legislador supremo, administrador supremo y juez supremo. Es líder del partido, del ejército y del pueblo. En su persona están unificados el poder del Estado, el pueblo y el movimiento. (...) Esa persona es Führer vitalicio. (...) Es independiente de las demás instituciones. (...) Es derecho lo que el Führer desea y la legislación emana de su poder. De modo semejante, el Führer encarna el poder administrativo, que es ejercido en su nombre. Es el jefe supremo de las fuerzas armadas y juez supremo e inapelable. Su poder es legal y constitucionalmente ilimitado. (...) El liderazgo supremo no es una institución que regulen normas y precedentes ni un cargo de autoridad delegada, sino la investidura del poder en una persona, Adolf Hitler. La justificación de este principio es carismática: se basa en la afirmación de que el Führer está dotado de cualidades que no tiene el común de los mortales. De él emanan cualidades sobrehumanas que penetran en el Estado, el partido y el pueblo. (...) En períodos de guerra civil, de perturbación religiosa y profundas conmociones sociales y económicas que producen miseria y dolor, los hombres son a veces incapaces $-\mathrm{o}$ se les hace deliberadamente incapaces- de percibir las leyes del proceso que les ha llevado a esa situación. Los estratos menos racionales de la sociedad buscan líderes. Como los hombres primitivos, buscan un salvador que elimine su miseria y les libre de la pobreza. Hay siempre un factor de cálculo, con frecuencia en ambas partes. El líder usa y realza el sentimiento de temor reverente; los secuaces se aborregan junto a él para alcanzar sus fines. La obediencia es un elemento necesario del liderazgo carismático, tanto la obediencia subjetiva — en cuanto carga onerosa-, como la objetiva - en cuanto medio de exigir el cumplimiento del deber ${ }^{33}$.

Las doctrinas de legitimación del poder de Franco en España hicieron uso abundante y profuso de esas teorías del poder carismático para justificar el caudillaje español de un "César divino de victoria fulminante» (en palabras siempre hiperbólicas de Giménez Caballero, precursor de esas ideas desde la publicación de su obra Genio de España en 1932) ${ }^{34}$. Pero, a diferencia de los casos precitados, esa conformación de un nuevo tipo de autoridad carismática en torno a la figura de un jefe militar que libra y gana una guerra civil tuvo, como hemos señalado, varios componentes confluyentes muy singulares: a) un aporte militar que apuntaló siempre su condición de Generalísimo que ostentaba «todos los poderes del Estado» por delegación expresa de sus compañeros de armas; b) un aporte religioso que le convirtió en Cruzado de la Fe de Cristo y «hombre providencial» ungido por Dios para regir la nación; y c) un aporte político que le situó como Jefe Nacional del único partido oficial del régimen «sólo responsable ante Dios y ante la Historia».

El resultado de la fusión en un «único mando» personal de esos poderes de legitimación de la autoridad de extracción tan diversa (militar, religiosa y

33 NEUMANN, 1983: 108-109 y 121. Una completa exposición de la filosofía política y jurídica nacional-socialista (precedida de un prólogo esclarecedor de Luis Legaz Lacambra) en LARENZ, 1942.

34 ÁLVAREZ CHILLIDA, 2010. MARTÍN GIJÓN, 2011. 
política) y, sin embargo, complementaria, fue la atribución a Franco del título de «Caudillo de España», por suma conjunta de la voluntad del Ejército, por la Gracia de Dios administrada por la jerarquía católica y por derivación de la jefatura del partido único estatal que agrupaba y organizaba a sus partidarios civiles. Un buen ejemplo de esa simbiosis en el plano propagandístico cabe apreciarlo en la portada del diario $A b c$ (el de «mayor circulación de la España nacional») con ocasión del segundo aniversario del «Alzamiento Glorioso del Ejército», el 17 de julio de 1938. Su texto (que podría ser arquetipo de los homenajes de la prensa franquista en aquella ocasión) era toda una declaración de fe del combinado de nacional-catolicismo, nacional-militarismo y nacional-sindicalismo cuyo vértice y clave de bóveda era la figura carismática del Caudillo:

Creemos en Dios. Creemos en España. Creemos en Franco.

Esperamos en Dios. Esperamos en España. Esperamos en Franco.

Amamos a Dios. Amamos a España. Amamos a Franco. (...)

Nuestra compenetración con el ideal de la Patria tradicional y unida, fiel al espíritu de los muertos gloriosos de la Cruzada, de sus mártires y de sus héroes, tiene hoy signo estricto, inequívoco, que nos viene señalado por la mano de Dios y por el propio Destino de España. Ese signo es Franco. Con Franco, con el Movimiento Nacional, que no solamente acaudilla, sino del cual es artífice, inspirador y creador, con cuanto Franco piensa, siente y quiere nos reiteramos solemnemente identificados este día 18 de julio al conmemorar la fecha en la que la fe y el amor patriótico del hombre providencial redimieron a España ${ }^{35}$.

Por supuesto, el paso del tiempo no modificaría el tono de la celebración pese a los cambios de contexto. A título ilustrativo, el 18 de julio de 1946 el diario Extremadura (Cáceres) llevaba en portada un retrato de Franco con el epígrafe de «CAUDILLO Y SEÑOR» que reiteraba sus cualidades excepcionales: «Franco, Capitán de la Victoria, Caudillo Nacional de la Falange, Generalísimo de los Ejércitos, Jefe del Estado, es síntesis de la alta virtud española salvada en julio de 1936». Y 20 años después, con ocasión de la festividad del 1 de octubre de 1966, el mismo diario renovaba sus votos de lealtad al «Caudillo de España» en agradecimiento por los treinta años de paz y prosperidad logrados bajo su mandato y «pidiendo a Dios siga bendiciéndole en la alta tarea, conservando largos años su preciosa vida para bien de la Patria, a su mano confiada».

$35 A b c, 17$ de julio de 1938, p. 23. LANGA, 2007: 85-102. 


\section{EL CULTO CARISMÁTICO DEL CAUDILLO ESPAÑOL Y SU FORMULACIÓN JURÍ- DICO-POLÍTICA}

El consecuente culto a la personalidad de Franco como Caudillo de España (y a veces también y sin exclusión: «de la Cruzada», «de la Victoria», «del Imperio», «de la Neutralidad», «de la Paz», «de la Fe», «de la Patria», «de la Nueva España») no fue sólo canalizada por la prensa escrita, naturalmente ${ }^{36}$. Aparte de otros medios publicitarios y propagandísticos entonces todavía quizá menos difundidos (como la radio, los noticiarios cinematográficos, la cartelística, los sellos de correos, más tarde la televisión, etc.), también contribuyó a ese propósito la educación formal a través de varios canales (el retrato oficial en las aulas, las menciones en los textos de manuales escolares, los ritos y ceremonias públicas de homenaje). Buen ejemplo de estas fórmulas es la referencia a Franco en el Catecismo patriótico español, libro declarado «de texto para las escuelas» por orden del Ministerio de Educación Nacional en enero de 1939, que era obra del dominico fray Albino González Menéndez-Reigada (obispo de Tenerife en 1924 que en 1946 lo sería de Córdoba). En sus páginas se explicaba a los niños que el Estado español estaba «bajo la suprema autoridad del Caudillo, Generalísimo Franco» y que éste era «como la encarnación de la Patria y tiene el poder recibido de Dios para gobernarnos ${ }^{37}$. Varios lustros después (1953), una de las habituales enciclopedias escolares para el grado medio (entre $10 \mathrm{y}$ 12 años) reiteraba todo lo que un pequeño español debía saber al respecto de manera igualmente catequética: «¿Qué es el Estado? Es la nación organizada para el cumplimiento de sus fines. El Estado español tiene un jefe, que es el Caudillo Franco» ${ }^{38}$. Y todavía en 1964 el joven escolarizado de 10 años era instruido en el significado del «Día del Caudillo» con una completa explicación político-ideológica a tono con los fundamentos del régimen:

El 1 de octubre de 1936, Franco fue elegido en Burgos Jefe del Estado y Caudillo de España. A partir de dicha fecha consagró por entero su vida y su saber a la Patria y si durante la Guerra de Liberación consiguió brillantes victorias militares, llegada la paz ha conseguido no menos resonantes triunfos políticos. En agradecimiento a sus servicios, prometámosle en este día nuestra adhesión y cariño ${ }^{39}$.

36 Meras ilustraciones de cada una de esas variaciones pueden verse en las portadas de estos diarios diversos: Extremadura (Cáceres), 18 de julio de 1940, 1 de abril de 1959 y 31 de marzo de 1962; Arriba (Madrid) 7 de septiembre de 1943 y 8 de mayo de 1945; El Alcázar (Toledo) 22 de octubre de 1937; ABC (Sevilla), 1 de octubre de 1937; El Heraldo de Aragón (Zaragoza), 20 de abril de 1937.

37 GONZÁLEZ MENÉNDEZ-REIGADA, 1939: 33 y 70.

38 ONIEVA Y TORRES, 1953: 32.

39 ÁLVAREZ PÉREZ, 1964: 264. 
Al margen de la propaganda política de mayor o menor calidad y de las aportaciones de los dirigentes políticos y periodistas oficiales, la elaboración del consecuente cuerpo doctrinal legitimador quedó a cargo de un notable grupo de juristas que ocuparon mayormente las influyentes cátedras de Derecho Político y Filosofía del Derecho de la Universidad española (convenientemente depurada de enemigos) y que dirigieron y coparon el nuevo Instituto de Estudios Políticos creado en 1939 para servir a esos mismos fines y propó$\operatorname{sitos}^{40}$.

Una de las primeras plumas en esa tarea fue el joven y prolífico jurista tradicionalista Francisco Elías de Tejada Spínola (1917-1978), que pronto sería catedrático en Salamanca y luego en Sevilla y Madrid. Apenas lograda la victoria en 1939, su folleto La figura del Caudillo afirmaba que el Caudillo era «esencialmente un jefe militar» triunfante, un «nuevo Alejandro», que «no tiene talón de Aquiles» y es «fuente de soberanía» porque «es el predestinado de Dios para regir una sociedad política en los momentos en que la normal organización de la misma no puede cumplir su misión». Y a tono con su filiación, reclamaba como soporte intelectual tanto la teología política católica (Donoso Cortés y Jaime Balmes) como los tratadistas modernos afines (Carl Schmitt y los fascistas italianos Cesarini Sforza y Carlo Costamagna $)^{41}$.

De manera paralela y contemporánea, otro jurista de filiación falangista formado en Bolonia, Juan Beneyto Pérez (1907-1994), emprendía también en 1939 una larga tarea de justificación doctrinal con el aval de Arrigo Solmi, ministro de Justicia de Mussolini. Su famoso libro titulado El Nuevo Estado Español subraya el origen militar del Caudillo como exigencia «del principio de unidad de mando» que había devenido «conductor en la guerra» y «conductor en la paz» porque es «Jefe supremo y total» con una función principal: «gobernar no es sólo ejecutar, sino mandar, legislar principalmente». Y terminaba recordando aprobatoriamente las palabras del secretario general de FET y de las JONS, Raimundo Fernández Cuesta, al respecto:

El Caudillo no es un jefe de Gobierno ni un dictador vulgar. Es el Jefe carismático, el hombre señalado por el dedo de la Providencia para salvar a su pueblo. Figura más que jurídica, histórica, filosófica, que escapa de los límites de la ciencia política para entrar en el de héroe de Carlyle o en el de superhombre de Nietzsche ${ }^{42}$.

40 SESMA LANDRÍN, 2004 y 2010. RIVAYA, 1998. CLARET MIRANDA. 2006: 352353. Según Claret, la plantilla de catedráticos existente en 1935 quizá se redujo en la mitad como consecuencia de las muertes, expulsiones y salidas al exilio. En las Facultades de Derecho, la reducción afectó a 27 catedráticos y 28 profesores.

41 ELÍAS DE TEJADA, 1939.

42 BENEYTO PÉREZ, 1939: 113, 115-116, 165 y 168. A juicio certero de GALLEGO, 2014: 595, la obra era «uno de los más importantes textos de la época». 
Entrado ya el año 1941, en pleno momento culminante de identificación del régimen con las potencias del Eje germano-italiano beligerantes en la guerra mundial, otro jurista de renombre con cátedra en Madrid, Luis Jordana de Pozas (1890-1983), publicaba en la revista del Instituto de Estudios Políticos un denso artículo sobre «El principio de unidad» que partía de una premisa tajante: «Si el poder es unitario, ha de encarnar en un solo hombre que lo ejerza de un modo efectivo y personal». Por eso encomiaba la decisión de la Junta burgalesa de 1936 de anular «la división de poderes» y traspasar «todos los poderes del Estado» a Franco, incluyendo a su juicio no sólo la potestad legislativa y ejecutiva sino también «la función judicial» («aun cuando ese poder continúe ejercido por los jueces y tribunales»). La consecuente «institución» del «caudillaje», en la persona de Franco, era parte del proceso que estaban experimentando «los Estados surgidos de las revoluciones nacionales» (Italia, Portugal y Alemania, expresamente mencionadas como términos análogos). Y, a tono con la filiación nacional-católica del autor, una de las ventajas del caso español era precisamente la calidad religiosa del Caudillo, evocada por una cita de un discurso pronunciado en el II Consejo Nacional de FET:

Una sola autoridad legítima en su origen y en la vocación de su voluntad... rige, con la ayuda de Dios, los destinos de España hacia la realización de su empresa histórica, acaudillando la Revolución Nacional ${ }^{43}$.

Apenas un año después, en 1942, cuando el curso de la guerra mundial empezaba a tomar un cariz adverso para las potencias del Eje, otro jurista español falangista asumía la tarea de perfilar una «doctrina del caudillaje» para fundamentar la legitimidad de los poderes de Franco que se convertiría en canónica «pieza doctrinal» sobre el tema. Se trata de Francisco Javier Conde García (1908-1974), formado en Alemania bajo el magisterio de Carl Schmitt (al que tradujo al español) que sería catedrático de Derecho Político en la Universidad de Santiago de Compostela y luego de Madrid hasta ingresar en 1946 en el servicio diplomático y disfrutar de una larga y distinguida carrera. Conde iba a ser, por antonomasia, «el teórico del caudillaje» (Alberto Reig Tapia) y «uno de los intérpretes más lúcidos del Nuevo Estado» (Ferran Gallego) ${ }^{44}$.

Primero en artículos en el diario oficial de Falange, Arriba, y luego en formato de libro con un título resonante (Contribución a la doctrina del caudillaje), Conde subrayaba que el caudillaje era una institución que suponía la fusión de la máxima voluntad de unidad de mando y de la fe en un hombre

43 JORDANA DE POZAS, 1941: 41-44.

44 REIG TAPIA, 2005: 191. GALLEGO, 2014: 553 y 617. 
providencial legitimado carismáticamente (aun cuando esa legitimidad no excluyera, sino que asumiera, la tradición española). No en vano, en su argumentación, «acaudillar es, ante todo, mandar legítimamente» (no mera dictadura provisoria, según la terminología de Schmitt), «acaudillar es mandar carismáticamente» (porque la excepcionalidad del caudillo genera devoción sin límite) y «acaudillar es mandar personalmente» (porque el poder en emergencias es indiviso para ser eficaz y no cabe limitar sus decisiones por ningún motivo formal). Y en justa apreciación de la necesidad de integración de otras culturas políticas afines (y de la incertidumbre de los tiempos venideros), Conde también añadía que la legitimidad carismática podía asumir la legitimidad tradicional gracias al proceso constituyente en curso (convocatoria de Cortes, posterior definición del Estado como «reino»...): «El predominio del elemento carismático en el caudillaje tampoco excluye el principio de legitimidad tradicional» ${ }^{45}$.

Con menos aparato crítico pero igual convicción política, en ese mismo año de 1942, en pleno apogeo de la influencia nazi-fascista sobre el régimen español, un correligionario falangista explicaba en un sencillo manual la naturaleza de Salvador y Padre de la Patria del Caudillo por razón de su propia condición de guerrero victorioso e invicto, que le facultaba para emprender la senda de la regeneración palingenésica de una España redimida por la sangre y la espada de sus pecados contra Dios y la Historia:

Cuando una Nación llega al Estado de descomposición a que había llegado la nuestra no tiene ya salvación si no es yendo a un cambio profundo y social, con una nueva concepción del Estado, o sea, una revolución nacional, y esta revolución nacional exige al frente de ella la figura, no del «líder» del partido democrático, ni de un jefe de Gobierno, ni siquiera la del dictador vulgar y conocido, sino la figura de un Caudillo, es decir, el jefe carismático (don gratuito que Dios concede con abundancia a una criatura), el hombre señalado por el dedo de la Providencia, que escapa de los límites de la ciencia política para entrar en la del «héroe sobrenatural»o en el del superhombre. (...) El caudillaje es reverencia ante lo superior y surge por mandato de Dios reflejado en el suceder histórico, y por lo tanto el Caudillo nazca solo, erguido sobre sus propios merecimientos, y cuando llega este momento es indiscutido e indiscutible. Se le acepta como Caudillo por la luz de su espada para vencer, por la claridad de sus decisiones para juzgar, por la agudeza de su mirada para mandar y señalar rumbos, y el Destino dio a España este hombre excepcional en el más doloroso de todos los trances ${ }^{46}$.

También 1942 fue testigo de la aparición de la segunda edición revisada de un texto doctrinal que trataba de definir, desde postulados católicos integris-

45 CONDE, 1942: 17, 23, 31 y 34. Los artículos previos fueron publicado por Arriba entre el 4 y 8 de febrero de 1942.

46 MORET MESSERLI, 1942: 71-72. 
tas, la especificidad del régimen español en el contexto internacional y como resultado de «la honda crisis de la democracia histórica». Su autor era Luis del Valle Pascual, catedrático de Derecho Político en Zaragoza, y el título de su obra Democracia y Jerarquía. Era una tentativa de explicación del origen y estructura del régimen a partir de la idea de superación de «la democracia puramente formal, inorgánica y totalmente empírica de los forjadores del constitucionalismo», regímenes viciados por ser «democracias de masas, de mayorías numéricas, niveladoras e igualitarias, democracias de individuos». Para ello, formulaba y recogía conceptos e ideas que habrían de tener amplia circulación en años posteriores, cuando la derrota del Eje se hubiera consumado y la victoria de las democracias occidentales obligase a reformular categorías definitorias del «Nuevo Estado Español».

Del Valle postulaba la mayor eficacia de unos modelos de «democracias orgánicas», basadas en las formas sociales básicas (las corporaciones, familias, municipios clásicos) y articuladas por «una jerarquía de mandos» según «un principio justo de selección». A su frente estaría un «Jefe del Estado» que fuera «la cúspide de esta selección de ciudadanos», surgido «mediante la voluntad expresa del Pueblo por aclamación entusiasta o votación plebiscitaria», que era así receptor de «su confianza plena y entera» y devenía «supremo Jefe y Director, Conductor y Guía de un Pueblo». Por supuesto, el mejor modelo de tal sistema era «el de la España actual, alrededor de la magna figura del Caudillo», un líder carismático y providencial que garantizaba «una más perfecta unidad de dirección y decisión soberanas». Un Caudillo, además, que por su historial y trayectoria «servirá el plan divino y se acercará a los designios de Dios» ${ }^{47}$.

Un repaso exhaustivo a esa publicística jurídico-política generada por el propio régimen durante los años cruciales de la guerra civil y la guerra mundial obligaría a mencionar los trabajos de otros juristas o politólogos igualmente prestigiosos en mayor o menor medida (Luis Legaz Lacambra, Luis Sánchez Agesta, José Antonio Maravall, José Pemartín, Ignacio María de Lojendio, Juan Candela-Martínez, etc. $)^{48}$. Pero esa ampliación del campo de mira apenas variaría el perfil del proceso de creación del carisma caudillista de Franco en sus distintos ámbitos de realización. Y tampoco alteraría el papel crucial que desempeñó en ese proceso la tríada de pilares institucionales que sostenía su régimen de autoridad personal y servían como dominios de escenificación ceremonial, ritual y simbólica de su triple condición de mitificado Generalísimo, hombre providencial y supremo Pater Patriae.

47 VALLE PASCUAL, 1942: 9, 162-164, 218 y 239. La primera edición de la obra era de 1938.

48 Todos ellos se analizan, en mayor o menor grado, en las obras citadas de GALLEGO, 2014; SAZ, 2003; REIG TAPIA, 2005; RIVAYA, 1998; y CUENCA TORIBIO, 2008. 
El paso del tiempo y el cambio de contextos internacionales no modificarían sustancialmente esa doctrina oficial de legitimación carismática del régimen español, ni siquiera cuando la derrota de los fascismos y el breve ostracismo internacional sufrido por la dictadura más daño hicieron a sus credenciales jurídicas y políticas dentro y fuera de España. Aunque, eso sí, el paso del tiempo y mudanza de escenarios modificara y mucho la conceptualización de la naturaleza del régimen: y ahí tiene su lugar la transición sin traumas desde el Estado nacional-sindicalista que configura el Fuero del Trabajo (1938) a la democracia católica y orgánica que prescribe el Fuero de los Españoles (1945), a la monarquía católica, social y representativa de la Ley de Sucesión (1947) y al Estado de administración racional de obras y servicios que postula la Ley Orgánica del Estado $(1967)^{49}$.

La lectura de las formulaciones jurídicas oficiales posteriores a 1945 prueba esa persistencia del caudillaje bajo nuevos moldes institucionales y nuevos marcos conceptuales. En 1951, con la España de Franco en proceso de lenta rehabilitación en el contexto de guerra fría mundial, un joven jurista llamado Manuel Fraga Iribarne (1922-2012), que entonces era catedrático de Derecho Político en Valencia (luego lo sería en Madrid), renovaba la fundamentación carismática tradicional con algunas dosis de validación tecnocrática y funcionalista más acorde con los nuevos tiempos vigentes (y subrayando conscientemente su excepcionalidad y consiguiente irrepetibilidad). Su libro se titulaba Así se gobierna España y estaba destinado, principalmente, a los círculos internacionales occidentales en cuyo seno trataba de reintegrarse el régimen de manera parcial y tentativa, pero con creciente éxito:

El pueblo español, en plena crisis de convivencia, había aceptado la suprema jefatura de Franco para que éste derrotase militarmente al comunismo; pero, al mismo tiempo, le pedía que le constituyese políticamente, entregándole el más auténtico caudillaje, en el sentido propio de la palabra. Visto el fracaso de las asambleas para constituir al país desde la crisis de 1931, se deseaba que esta vez fuese un solo y verdadero caudillo el que diese nuevas leyes, nueva constitución a la comunidad. Como Solón, como Cromwell, como tantos otros héroes nacionales, el General Franco debía ser Padre de la Patria que la volviese a la normalidad y al orden. (...) En la actualidad, el Jefe del Estado asume al mismo tiempo la Presidencia del Gobierno y ocupa una situación más parecida a la de un Presidente de una República presidencialista que a la de un Regente. No olvidemos que su situación es propiamente la de una magistratura de emergencia. Es decir, que el mando de Franco supone una concentración extraordinaria de poderes para hacer frente a unas circuns-

49 Un actualizado análisis de la evolución institucional en GIMÉNEZ MARTÍNEZ, 2014. Una introducción al debate sobre «la naturaleza del franquismo» en MORADIELLOS, 2015: 311-350. 
tancias difíciles; pero no un poder tiránico impuesto a la Nación, que le reconoció en todas las ocasiones por su caudillo ${ }^{50}$.

Apenas una década más tarde, en 1961, otro catedrático de esa misma disciplina (en la Universidad de Oviedo) y similar protagonismo político posterior, Torcuato Fernández-Miranda (1915-1980), escribía un manual de texto muy difundido que sería una de las últimas formulaciones doctrinales del caudillaje adaptado a los nuevos tiempos del desarrollismo tecnocrático. Fernández-Miranda Hevia rescataba, desde luego, el magisterio de Weber y sus tres tipos de legitimidad política (racional, tradicional y carismática), pero la entroncaba con el pensamiento tradicional católico español y sus tres tipos de autoridad legal (por sucesión, elección y adquisición o conquista). Además, explicaba y justificaba el caudillaje con razones históricas y funcionalistas muy explícitas (y otra vez excepcionales e irrepetibles):

\begin{abstract}
Si en una situación de grave peligro, un buque se queda sin capitán y sin nadie que normalmente le sustituya, la persona que, en medio de la anarquía, fuera capaz de imponer su voz y su mando, se constituiría automáticamente, con toda legitimidad, en capitán del buque. De igual modo, la persona que, en situaciones de naufragio social, vacante y en situación de nullius el ejercicio de la potestad, es capaz de suscitar la adhesión del pueblo y constituirse en director o conductor del mismo, se constituye, excepcionalmente, pero con título legítimo indudable, en Caudillo. La doctrina expuesta es, en último término, la doctrina de la conquista, como origen legítimo del poder, de Santo Tomás de Aquino y de nuestros teólogos juristas españoles de nuestra Edad de Oro, Vitoria, Suárez, etc. Pues bien, a estos conceptos responde (...) el caudillaje, establecido como una situación originaria de excepción. El proceso de permanente guerra civil, latente o expresa, de la vida española desde Fernando VII, se hunde en la anarquía en la Segunda República, que hizo inevitable la guerra civil. De ella surge, a través del Movimiento Nacional, suscitado por la adhesión de la España nacional, la figura del conductor o Caudillo de la Cruzada, en la persona de Francisco Franco ${ }^{51}$.
\end{abstract}

Finalmente, ya en 1973, en plena fase crítica del tardo-franquismo, veía la luz una influyente obra de José Zafra Valverde, miembro del Opus Dei y catedrático de Derecho Político en la Universidad de Navarra: Régimen político de España. Su autor reconocía sin ambages la singularidad de un régimen de «Caudillaje nacional» que confería a Franco «un cargo político en el que se concentra del modo más estricto la soberanía» y ello en «el doble sentido de la máxima potestad y la máxima autoridad» y sus derivaciones: «funciones de autoridad o control persuasivo, constituyentes, legislativas y de suprema administración, ejecutivas y jurisdiccionales». Y, por supuesto, tal concentración de

50 FRAGA IRIBARNE, 1951: 36-37 y 54.

51 FERNÁNDEZ-MIRANDA, 1963 (cuarta edición): 190. 
facultades soberanas tenía su fundamento en una «legitimidad de origen» (la victoriosa defensa contra la revolución comunista de 1936) combinada con una «legitimidad de ejercicio» (el progreso social y material logrado desde 1939) ${ }^{52}$.

Pero las formulaciones doctrinales generadas por esos círculos, con todas sus variaciones y modulaciones, no podían ocultar la naturaleza profundamente antiliberal y antidemocrática de ese régimen caudillista, naturalmente ${ }^{53}$. Pocos años después de la explicación de Fraga Iribarne y casi al mismo tiempo que la racionalización de Fernández-Miranda, el embajador francés en España resumía para sus superiores en París su juicio sobre el papel político del Caudillo con una fórmula lacónica y más próxima a la realidad esencial del fenómeno: Franco era lo más parecido a «un monarca absoluto y solitario» ${ }^{54}$. Aquel mismo año de 1959, un observador liberal y templado como era Salvador de Madariaga lo reiteraba de manera más taxativa y denunciatoria desde el exilio: Franco era un dictador autocrático a la par que «un reaccionario beato y cuartelero» ${ }^{55}$. Era una forma de señalar el persistente «pecado original» del franquismo como régimen de dictadura personal que ninguna doctrina jurídico-política podía ocultar ni deformar, a pesar de todos sus artificios retóricos verbales:

La historiografía (también cabría decir la doctrina jurídica) franquista no ha querido nunca plantearse el que fue el gran problema del régimen de Franco: que careció siempre de verdadera legitimidad moral ante la conciencia liberal y democrática del mundo contemporáneo, por su origen (alzamiento militar, guerra civil) y por su naturaleza autoritaria y represiva ${ }^{56}$.

\section{Biblografía}

Álvarez Bolado, Alfonso, Para ganar la guerra, para ganar la paz. Iglesia y guerra civil, Madrid, Universidad Pontificia de Comillas, 1995.

Álvarez Chillida, Gonzalo, «Ernesto Giménez Caballero: unidad nacional y política de masas en un intelectual fascista», Historia y Politica, 24, (Madrid, 2010), 265-291.

Álvarez Pérez, Antonio, Enciclopedia Álvarez. Primer Grado, Valladolid, Miñón, 1964.

Álvarez Tardío, Manuel, «La CEDA y la democracia republicana», en Fernando del Rey (ed.), Palabras como puños. La intransigencia política en la Segunda República Española, Madrid, Tecnos, 2011; 341-418.

Andrés-Gallego, José, ¿Fascismo o Estado Católico? Ideología, religión y censura en la España de Franco, 1937-1941, Madrid, Encuentro, 1978.

52 ZAFRA VALVERDE, 1973: 164-167, 195 y 200.

53 SAZ, 2013: 113-133.

54 Palabras de un informe confidencial de Guy de la Tournelle en octubre de 1959. FLEITES MARCOS, 2009: 152.

55 MADARIAGA, 1959: 10.

56 FUSI, 1985: 15. 
Arrarás, Joaquín, Historia de la Segunda República, Madrid, Editora Nacional, 1968, 4 vols.

Beneyto Pérez, Juan, El Nuevo Estado Español. El régimen nacional-sindicalista ante la tradición y los demás sistemas totalitarios, Madrid, Biblioteca Nueva, 1939.

Besier, Gerhard y Stoklosa, Katarzyna, European Dictatorships. A Comparative History of the Twentieth-Century, Newcastle, Cambridge Scholars Publishing, 2013.

Blinkhorn, Martin, Carlismo y contrarrevolución en España, 1931-1939, Barcelona, Crítica, 1979.

Bracher, Karl Dietrich, The Age of Ideologies. A History of Political Thought in the XXth Century, Londres, Methuen, 1984.

Canal, Jordi, Banderas blancas, boinas rojas. Una historia política del carlismo, 1876-1939, Madrid, Marcial Pons, 2006.

Cardona, Gabriel, Historia militar de una guerra civil, Barcelona, Flor del Viento, 2006.

Cardona, Gabriel, El poder militar en el franquismo, Barcelona, Flor del Viento, 2008.

Casanova, Julián, Europa contra Europa, 1914-1945, Barcelona, Crítica, 2011.

Cavalli, Luciano, Carisma. La qualitá straordinaria del leader, Roma, Laterza, 1995.

Cazorla, Antonio, Franco. Biografia del mito, Madrid, Alianza, 2015.

Claret Miranda, Jaume, El atroz desmoche. La destrucción de la Universidad espanola por el franquismo, 1936-1945, Barcelona, Crítica, 2006.

Conde, Francisco Javier, Contribución a la doctrina del Caudillaje, Madrid, Vicesecretaría de Educación Popular, 1942.

Cuenca Toribio, José Manuel, Nacionalismo, franquismo y nacional-catolicismo, Madrid, Actas, 2008.

Davis, Sarah y Harris, James (eds.), Stalin. A New History, Cambridge, Cambridge University Press, 2005.

De Felice, Renzo y Goglia, Luigi, Mussolini. Il Mito, Roma-Bari, Laterza, 1983.

Di Febo, Giuliana, Ritos de guerra y de victoria en la España franquista, Valencia, Universidad de Valencia, 2012.

Eatwell, Roger, «Introduction: New Styles of Dictatorship and Leadership in Interwar Europe», Totalitarian Movements and Political Religions, 7/2, (Londres, 2006), 127-137.

Elías de Tejada, Francisco, La figura del Caudillo. Contribución al derecho público nacionalsindicalista, Sevilla, Ateneo de Sevilla-Tipografía Andaluza, 1939.

Fernández-Miranda, Torcuato, El hombre y la sociedad, Madrid, Ediciones DoncelDelegación Nacional de Juventudes, 1963.

Ferrando Badía, Juan, «Las formas históricas de poder político y sus legitimidades», Revista de Estudios Politicos, 138, (Madrid, 1964), 85-121.

Fleites Marcos, Álvaro, De Gaulle y España, Avilés, Azucel, 2009.

Fraga Iribarne, Manuel, Así se gobierna España, Madrid, Oficina de Información Diplomática, 1951.

Fusi, Juan Pablo, Franco. Autoritarismo y poder personal, Madrid, El País, 1985. 
Gallego, Ferran, El Evangelio Fascista. La formación de la cultura política del franquismo (1930-1950), Barcelona, Crítica, 2014.

Gallego, Ferrán, Ramiro Ledesma Ramos y el fascismo español, Madrid, Síntesis, 2005.

Gallego, Ferrán y Morente, Francisco (eds.), Fascismo en España, Barcelona, El Viejo Topo, 2005.

García-Pelayo, Manuel, Los mitos políticos, Madrid, Alianza, 1981.

Gentile, Emilio, El culto del Littorio. La sacralización de la política en la Italia fascista, Buenos Aires, Siglo XXI, 2007.

Gil Pecharromán, Julio, Conservadores subversivos. La derecha autoritaria Alfonsina (1913-1936), Madrid, Eudema, 1994.

Giménez Caballero, Ernesto, España y Franco, San Sebastián, Ediciones Los Combatientes, 1938.

Giménez Martínez, Miguel Ángel, El Estado franquista. Fundamentos ideológicos, bases legales y sistema institucional, Madrid, Centro de Estudios Políticos y Constitucionales, 2014.

González Calleja, Eduardo, Contrarrevolucionarios. La radicalización violenta de las derechas en la Segunda República, Madrid, Alianza, 2011.

González Cuevas, Pedro Carlos, Acción Española: Teología política y nacionalismo autoritario en España, Madrid, Tecnos, 1998.

González Cuevas, Pedro Carlos, El pensamiento político de la derecha española en el siglo XX, Madrid, Tecnos, 2005.

González Menéndez-Reigada, Padre, Catecismo patriótico español, Salamanca, Establecimiento Tipográfico Calatrava, 1939.

Jordana de Pozas, Luis, «El principio de autoridad y sus consecuencias políticas y administrativas», Revista de Estudios Políticos, 3-4, (Madrid, 1941), 621-640 y 33-53.

Kershaw, Ian, El mito de Hitler. Imagen y realidad en el Tercer Reich, Barcelona, Paidós, 2003.

Langa, Concha, «Abc de Sevilla, el diario de mayor circulación de la España nacional», en A. Checa, C. Espejo y M.J. Ruiz (coords.), ABC de Sevilla. Un diario y una ciudad, Sevilla, Universidad de Sevilla, 2007; 85-102.

Lannon, Frances, Privilegio, persecución y profecía. La Iglesia católica en España, 1875-1975, Madrid, Alianza, 1987.

Larenz, Karl, La filosofía contemporánea del Derecho y del Estado, Madrid, Revista de Derecho Privado, 1942 (traducción de Eustaquio Galán Gutiérrez y Antonio Truyol Serra).

Lindholm, Charles, Carisma, Barcelona, Gedisa, 2012.

Losada, Juan Carlos, Ideología del Ejército Franquista, 1939-1959, Madrid, Istmo, 1990.

Madariaga, Salvador de, General, Márchese usted, Nueva York, Ediciones Ibéricas, 1959.

Martín Gijón, Mario, Los (anti)intelectuales de la derecha española. De Giménez Caballero a Jiménez Losantos, Barcelona, RBA, 2011.

Martínez Reverte, Jorge, El arte de matar. Cómo se hizo la guerra civil española, Barcelona, RBA, 2009. 
Matthews, James, Soldados a la fuerza. Reclutamiento obligatorio durante la guerra civil, Madrid, Alianza, 2013.

Mazower, Mark, La Europea negra. Desde la Gran Guerra hasta la caida del comunismo, Barcelona, Ediciones B, 2001.

Mola, Emilio, Obras completas, Valladolid, Santarén, 1940.

Montero, Feliciano, La Acción Católica en la Segunda República, Alcalá, Universidad de Alcalá, 2008.

Montero, José R., La CEDA: el catolicismo social y político en la Segunda República, Madrid, Revista de Trabajo, 1977, 2 vols.

Moradiellos, Enrique, «Franco y el franquismo en tinta sobre papel: narrativas sobre el régimen y su caudillo», en Julián Casanova (dir.), 40 años con Franco, Barcelona, Crítica, 2015; 311-350.

Moret Messerli, Francisco, Conmemoraciones y fechas de la España nacionalsindicalista, Madrid, Delegación Nacional de Prensa y Propaganda de FET, 1942.

Morodo, Raúl, Los orígenes ideológicos del Franquismo: Acción Española, Madrid, Alianza, 1985.

Mosse, George L., Fallen Soldiers. Reshaping the Memory of the Two World Wars, Oxford, Oxford University Press, 1990.

Neumann, Franz, Behemoth, Pensamiento y acción en el nacional-socialismo, México, Fondo de Cultura Económica, 1983.

Novella Suárez, Jorge, El pensamiento reaccionario español, 1812-1975. Tradición y contrarrevolución, Madrid, Biblioteca Nueva, 2007.

Onieva, Antonio J. y Torres, Federico, Enciclopedia Hernando. Grado Medio, Madrid, Librería y Casa Editorial Hernando, 1953.

Orella, José Luis, La formación del Estado Nacional durante la guerra civil, Madrid, Actas, 2001.

Overy, Richard, Dictadores. La Alemania de Hitler y la Unión Soviética de Stalin, Barcelona, Tusquets, 2006.

Passerini, Luisa, Mussolini immaginario. Storia di una biografí, 1915-1939, Bari, Laterza, 1991.

Platón, Miguel, Hablan los militares. Testimonios para la historia, Barcelona, Planeta, 2001.

Primo de Rivera, José Antonio, Textos de doctrina política, Madrid, FET de las JONS, 1966.

Preston, Paul, Las derechas españolas en el siglo XX, Madrid, Sistema, 1986.

Preston, Paul, Franco. Caudillo de España, Barcelona, Grijalbo, 1994.

Reig Tapia, Alberto, Franco. El César superlativo, Madrid, Tecnos, 2005.

Ridruejo, Dionisio, «La Falange y su Caudillo», FE. Revista mensual de doctrina Nacional-Sindicalista, 4-5 (Zaragoza, 1938), 35-38.

Rivaya, Benjamín, Filosofía del Derecho y primer franquismo, Madrid, Centro de Estudios Políticos y Constitucionales, 1998.

Rodríguez Aisa, María Luisa, El cardenal Gomá y la guerra de España, Madrid, CSIC, 1981. 
Rodríguez Jiménez, José Luis, La extrema derecha española en el siglo XX, Madrid, Alianza, 1997.

Ruiz Carnicer, Miguel Ángel (ed.), Falange. Las culturas politicas del fascismo en la España de Franco, Zaragoza, Institución Cultural Fernando el Católico, 2013.

Saz, Ismael, España contra España. Los nacionalismos franquistas, Madrid, Marcial Pons, 2003.

Saz, Ismael, Fascismo y Franquismo, Valencia, Universidad de Valencia, 2004.

Saz, Ismael, «Franco, ¿Caudillo fascista? Sobre las sucesivas y contradictorias concepciones falangistas del Caudillaje franquista», en Ismael Saz (ed.), Las caras del franquismo, Granada, Comares, 2013; 113-133.

Schmitt, Carl, La dictadura, Madrid, Alianza, 2013.

Seidman, Michael, La victoria nacional. La eficacia contrarrevolucionaria en la guerra civil, Madrid, Alianza, 2012.

Sesma Landrín, Nicolás, «Propaganda a la alta manera e influencia fascista. El Instituto de Estudios Políticos», Ayer, 53 (Madrid: 2004), 155-178.

Sesma Landrín, Nicolás, Antología de la Revista de Estudios Políticos, Madrid, Centro de Estudios Políticos y Constitucionales, 2010.

Sevillano, Francisco, Franco. Caudillo por la Gracia de Dios, Madrid, Alianza, 2010.

Stuart Hughes, Henry, Conciencia y sociedad. La reorientación del pensamiento social europeo, 1890-1930, Madrid, Aguilar, 1972.

Thomàs, Joan María, Lo que fue la Falange, Barcelona, Plaza y Janés, 1999.

Thomàs, Joan María, Los fascismos españoles, Barcelona, Planeta, 2011.

Thomàs, Joan María, El gran golpe. El «caso Hedilla» o cómo Franco se quedó con la Falange, Barcelona, Debate, 2014.

Traverso, Enzo, A sangre y fuego. De la guerra civil europea, 1914-1945, Buenos Aires, Prometeo, 2009.

Tusell, Javier, Historia de la democracia cristiana en España, Madrid, Cuadernos para el Diálogo, 1974, vol. 1.

Ullmann, Walter, Historia del pensamiento político en la Edad Media, Barcelona, Ariel, 2013.

Valle Pascual, Luis del, Democracia y Jerarquí, Zaragoza, Atheneum, 1942.

Vigón, Jorge, Historia de España, Madrid, Fax, 1934.

Weber, Max, Sociología del poder. Los tipos de dominación, Madrid, Alianza, 2007.

Weber, Max, Economía y Sociedad, México, Fondo de Cultura Económica, 2014.

Zafra Valverde, José, Régimen Político en España, Pamplona, Universidad de Navarra, 1973.

Zenobi, Laura, La construcción del mito de Franco, Madrid, Cátedra, 2011.

Recibido: 04/05/2015

Aprobado: 18/01/2016 